\title{
NOTES
}

1. For his biography see Fuad Köprülü, "Abdullah Tukay," Türk Yurdu (1913), pp. 497-515; A. B. Taymas, "Kazanli şâir Abdullah Tukay üzerine (About the poet of Kazan Abdullah Tukay)," Türk Kültürü, Vol. I, No. 19, pp. 68-76; R. R. Arat, "Abdullah Tukay," Türk Kültürü, Vol. III, pp. 469-473; H. Zülfikar, "Abdullah Tukay," Türk Kültürü, Vol. VI, pp. 374-386; N. Devlet, "Kazan Türkleri ve Abdullah Tukay (The Turks of Kazan and Abdullah Tukay)," Kazan (1971), No. 3, pp. 3-11.

2. H. Hismetullin and Y. Agishev (Comp.), G. Tukay Saylanma Eserler (Selected Works) (Kazan, 1960), p. 7.

3. A. Saraf, ed. Tukayif süzleri (The Words of Tukayif) (Kazan, 1913).

4. N. Devlet, Rusya Türklerinin Millî Mücâdele Tarihi (1905-1917) (The History of the National Struggle of the Turks of Russia) (Ankara, 1985), pp. 171-186 and pp. 206-212.

5. Specially the literary organ of the Writers Union of Tataristan, the monthly magazine Kazan began on the occasion of the 100th anniversary of Tukay in 1985 a publishing campaign. So in every issue of Kazan there is at least one poem, a memoire or an article.

6. B.-Antonov and L. Velieva, Gabdulla Tukaynin edebi-memorial muzei (Gabdulla Tukay's literary-memorial museum) (Kazan, 1984), p. 40.

7. H. Gabdüsh, Tatar shagiri Gabdulla tukay (ülüvine 19 yil tulu unaya bilen) (The Tatar poet Gabdulla Tukay. On the occasion of his 19th anniversary), (Harbin, 1932).

8. Gabdulla Tukay Mecmua Asari (1913-1933) (Complete Collection of Gabdulla Tukay), Vols I-IV, (Tokyo, 1933).

9. Gabdulla Tukay (1913-1938) (Vafatina 25 yil tulu unayi bilen) (Gabdulla Tukay. On the occasion of his 25th anniversary) (Mukden, 1938).

10. H. Sadik, ed., Gadbulla Tukay şigirleri (Poems of Gabdulla Tukay) (Helsinki, 1969).

11. "Tukay Bülteni (Tukay Bulletin)" which was published bimonthly in Istanbul appeared in 24 issues in three years.

12. "Kazan" the organ of the Tatar Association of Istanbul (Kazan Türkleri Kültür ve Yardimlasma Derneği) has been published in 23 issues.

13. K. Dewletshin, "Tukaynin ijatinda ateizm (Atheism in Tukay's work)," Soviet Mektebi (1976), No. 4, pp. 29-31; See also N. Devlet, "Islam in Tataristan," Journal of the Institute of Muslim Minority Affairs Vol. V, (1985), No. 2, p. 340; Z. A., Ishmohemmetov, Ruhi Isirtkich (Spiritual Intoxicant) (Kazan, 1983), p. 52.

14. Gabdulla Tukay (1913-1938), p. 83

15. H. Hismetullin and Y. Agishev, ibid.; I. Nurullin, ed., Gabdulla Tukay, (Kazan, 1979); K. Bashirov, ed., Gabdulla Tukay, (Kazan, 1968).

16. For these poems see Gabdulla Tukay Mecmua Asari (1913-1933). For Vasiyetim (My Testament), Vol. 2, p. 20. See also Gabdulla Tukay (1913-1938), p. 58; Kazan, (1971), No. 3 p. 12. For Te'sir (Influence), Vol. I, p. 19; Mirac (Ascension of prophet Muhammed), Vol. I, p. 49; Qadir Kich (The 27th day of Ramadan), Vol. I, p. 159; Alla tebarek teale (God the Great), Vol. II, p. 1.

17. Kibla: Direction to which a Muslim turns when praying i.e. towards Mecca! . 


\section{Opposition in the USSR to the Occupation of Afghanistan}

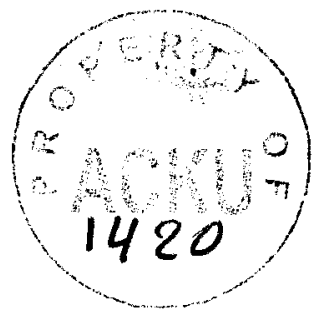

\section{TARAS KUZIO}

Opposition in the Soviet Union to the occupation of Afghanistan has taken many forms - cutting across national, religious, political and socio-economic backgrounds. Thus far, there appears little evidence to show that opposition in different areas has linked up to forge a mass movement similar to the American anti-war movement of the 1960 s. Soviet totalitarian control and repression would make this difficult. But, on some occasions, different nationalities have signed joint declarations. An exception to the above is that of Muslim Central Asia, where similar religious and ethnic backgrounds coupled with contact to Afghan guerrilla groups, has allowed a broader degree of opposition to emerge. ${ }^{1}$

Western press accounts of the Afghan war and its influence inside the USSR neglects many factors, often denying that any anti-war movement could develop. ${ }^{2}$ Yet Sergei Khovanski, an author living in Moscow, claimed that the war:

... constitutes a heavy burden for the economy and leads to an increase in the number of casualties, as well as being the cause of the emergence of spontaneous protest movements in the lower strata of society and division at the top levels. ${ }^{3}$

He also believed that a "powerful anti-war movement", comparable "to the one which shook the United States at the end of the 60 s and beginning of the $70 \mathrm{~s}$ " is unlikely in the USSR. This is because:

... the powers of the organs of repression in the USSR are much greater than in the US, while the political activism of the masses is much weaker. Nevertheless the Soviet leadership cannot disregard acts expressing massive anti-war sentiments in the country. ${ }^{4}$

Although the USSR is a totalitarian state, which does not tolerate criticism on sensitive questions such as the occupation of Afghani- 
stan, she is still not able to completely eradicate all vestiges of independent thought and feeling. The USSR is vulnerable as a multinational empire where many of its own nationalities feel strong sympathy for the Afghans because they too are victims of Soviet Russian imperialism. The occupation of Afghanistan has certainly accentuated those anti-Russian feelings which were already in evidence in the Baltic republics, Ukraine and Central Asia.

Therefore, it is not surprising to find that opposition to the occupation is greater in areas such as Muslim Central Asia, Ukraine and the three Baltic republics of Lithuania, Latvia and Estonia. One analyst of unofficial writing on Afghanistan concluded that, "This theme of guilt and national responsibility for the crime's of one's own government is more characteristic of Russian samizdat than of the samizdat of other peoples of the USSR". ${ }^{6}$ This was brought out in unofficial polls conducted with Soviet citizens, which also revealed that Russians showed the highest rate of approval of the occupation. The lowest rates of approval for Soviet policy in Afghanistan were in Central Asia, the three Baltic states and Ukraine. There also appeared a correlation between those who listened to Western radio stations and maintaining a dissenting view about Soviet policy in Afghanistan. ${ }^{7}$

Sergei Khovanski has also noticed that:

... dissatisfaction grows proportionately within those strata of Soviet society from which the soldiers are called up. It is interesting that among those nations which inhabit the periphery of the USSR this dissatisfaction more and more frequently takes the form of open resistance. Acts of protest are quickly and ruthlessly suppressed and for that reason information about them rarely becomes known to world public opinion. ${ }^{8}$

A greater awareness of the war in Afghanistan is evidenced from an article in the unofficial Polish newspaper, Robotnik (No.82, 1985). A Polish visitor to the Ukrainian port of Odessa found that, "the real cause of frustration is the war with Afghanistan. Not only we in Poland perceive parallels with the war in Vietnam. This war cannot be won." Growing disillusionment with the war was reflected in a survey conducted by Radio Liberty which found that only one quarter expressed approval of Soviet policy and had any confidence in its eventual success. 9

Besides samizdat, unofficial sources are also a supply of information and consist of foreign radio broadcasts, anti-Soviet literature smuggled into the USSR, accounts given by returning conscripts who are disabled or psychologically scarred from their experiences, contact with relatives aborad and non-Soviet television in republics such as Estonia and Moldavia (where Finnish and Romanian television can be received and understood). ${ }^{10}$

Until 1983 the Soviet press played down any mention of Soviet ac- 
tivity in Afghanistan. The low volume of reporting prompted a Soviet sergeant stationed in Afghanistan to write to Komsomolskaya Pravda (10 February 1984): “To be honest, I'm surprised at how little is written about Afghanistan and about the Soviet people who are honourably doing their duty, often risking their lives".

High Soviet casualties, and the need to prepare the Soviet public for a long war, have also required the Soviet press to be more open. Secret information from the Ministry of Defence estimated casualties as of September, 1980 as 8492 killed and 15,000 wounded. ${ }^{11}$ A report taken from a dead Soviet officer gave casualties two years later at between 32,000-42,000 dead and wounded. ${ }^{12}$ Mykola Movchan, a Ukrainian deserter in Afghanistan, revealed that talk among his comrades was of losses in the region of 100,000 . In his view this was too high, and he believed the true figure to be $40-50,000 .{ }^{13}$ Estimates in the region of 40,000 dead and wounded appear in a variety of sources. The samizdat Lithuanian journal, Ausra, claimed that, "For three years, as officials themselves state, up to $30 \%$ of the army perished or was wounded" ( 30 percent of the Soviet troop level of 120,000 is $40,000)$. $^{14}$

More recent sources give even higher casualty figures. According to a statement made by Procurator V. I. Chistyakov in September 1985 , to the House of Political Education attached to the Moscow CPSU, 15,000 Soviet soldiers and officers die each year in Afghanistan. ${ }^{15}$ A Moscow sales clerk seemed to confirm these high figures when she stated:

According to American radio broadcasts, we have lost 10,000 or 15,000 men in Afghanistan, but $I$ believe that in reality the figure is much higher: maybe 30,000 or 40,000 . A friend of mine, who goes out to the freight terminal at Sheremetevo (Moscow) airport almost every day, tells me that a special plane carrying around one hundred coffins lands there every day. ${ }^{16}$

Since 1983-84 the Soviet press has reported the existence of Soviet casualties, elevating many of them to hero figures. ${ }^{17}$ Undoubtedly pressure from below was also a factor here - there are many examples of burials of dead soldiers being turned into spontaneous antiregime demonstrations. In March 1981 reports circulated of Kazakhs in Alma-Ata staging a demonstration demanding proper Muslim burial for soldiers killed in Afghanistan. ${ }^{18}$ Some reports suggest that fear of these funerals turning into focal points for anti-regime demonstrations have made the authorities reluctant to send bodies home for burial.

News of casualties causes distress and anger. In July 1985 a Soviet soldier stationed in East Germany heard that his brother had been killed in Afghanistan. He was killed whilst attempting to leave the garrison with a gun with the wish of returning home. ${ }^{19}$ In 1984 a 
woman set herself alight in front of the Party headquarters in the Ukrainian town of Kharkov, after she was unable to obtain the body of her son, killed in Afghanistan. ${ }^{20} \mathrm{~A}$ chemist from Kalinin witnessed an angry demonstration by 500 people in front of the city's Party headquarters. A large crowd had quickly gathered after a woman became hysterical upon hearing that her son had been killed in Afghanistan. Many of those who joined the demonstration did so because they also had sons in Afghanistan. ${ }^{21}$

Opposition to the occupation manifests itself in many different forms: involvement in underground publishing and dissident activity, demonstrations outside recruitment offices and at the funerals of those killed, attempts to avoid enlistment by paying huge bribes, feigning illness or madness. ${ }^{22}$ A Moscow physician observed that "the military authorities are concerned about the high rate of simulated illnesses among draftees who will stop at nothing to avoid conscription - including self-imposed injuries, self-poisoning and feigning madness". ${ }^{23}$ A Ukrainian physician from Kirovgrad who worked in a military registration office witnessed huge offers of bribes to exempt boys from being sent to Afghanistan: "One father . . . even offered me a house or a car to have his son exempted". To reduce complications with parents, orphaned children are being sent to Afghanistan, he claimed. ${ }^{24}$

In addition to the samizdat which is against the war in Afghanistan, the re is also magnitizdat - tape recordings of songs copied and passed around illegally. These songs were composed in Afghanistan, collected by a Soviet officer and circulated in the Soviet Union. English translations have appeared in the Los Angeles Times and in Russian in the New York daily, Novoe Russkoe Slovo. ${ }^{25}$ The songs speak of the burden of the war and reflect a strong desire to return home. They are composed by the elite of the Soviet army - the airborne forces which goes some way to explaining their militaristic nature. A samizdat author describes the songs as a "complex of ideas reflecting, in essence, the imperial pretensions of Soviet foreign policy". In addition, these beliefs are not surprising in view of reports of pro-fascist demonstrations in Pushkin square, Moscow, in August 1982 by former airborne troops with service in Afghanistan. ${ }^{26}$

Moscow has encountered disillusionment from the 400,000 Soviet soldiers who have served in Afghanistan. A fake Russian-language copy of the army newspaper, Krasnaya Zvezda, with a picture of a soldier breaking his kalashnikov over his legs with the caption "Stop the War! Let us Go Home!" was circulated in Kabul towards the end of 1983. The response from discontented Soviet soldiers was to send articles and letters to the real Krasnaya Zvezda in Moscow. The fact that a fake copy of the army newspaper elicited such a response is in- 
dicative of the unhappiness among many conscripts at being in Afghanistan. ${ }^{27}$ Sergei Khovanski has pointed out that, "The process of demoralisation of officers and men went hand in hand with increasing cruelty towards peaceful inhabitants of the country". ${ }^{28} \mathrm{He}$ believed that as the "human losses" have increased opposition to the war has risen.

Disgruntled former soldiers who have served in Afghanistan are a problem for the Soviet authorities. Some veterans have given interviews to the underground press, ${ }^{29}$ whilst even the official press has begun to discuss the problems faced by emotionally scarred soldiers from Afghanistan. ${ }^{30}$ Sergei Khovanski believes that,

the anti-war mood of the Soviet youth has already become a serious problem for the High Command of the armed forces. If these moods were to acquire a clearer political shade, such a development could be fraught with serious consequences for the whole of the Soviet society. ${ }^{31}$

In addition, the psychological impact of Soviet defectors speaking over Radio Liberty or Voice of America to Soviet listeners must be tremendous. One wonders what they will feel when they hear that those who have decided to return to the USSR from the West have been sentenced to long terms of confinement in labour camps. Nikolai Ryzhkov defected in 1983 and received asylum in the USA. Two years later he returned to the USSR, where he was interrogated by the KGB for nine days and then given a twelve-year sentence. ${ }^{32}$

A Soviet civil servant, responsible for providing social services for Afghan veterans, admitted that, "until three years ago, we had difficulties in handling the special needs of veterans . . . who have returned from Afghanistan physically or emotionally handicapped". The population has had to "become more sensitive and sympathetic to the needs of veterans". ${ }^{33}$ Afghan veterans have recently been entitled to receive the same privileges as those given to Second World War veterans. ${ }^{34}$

Many of these disillusioned veterans have formed vigilante squads calling themselves "Afgantsi", who have military-style training and carry out their own brand of "justice" to those they consider to be "anti-social". They are disgruntled at the reality of Soviet life (speculation, corruption, bureaucracy, Western fashions among young people), the insufficient attention paid them by the local authorities, and frequently are bitter at the loss of comrades in Afghanistan. ${ }^{35}$ They believe that they have a "moral superiority" over people around them, and press for the formation of veterans clubs. ${ }^{36}$ The newspaper Komsomolskaya Pravda has shown the greatest interest in the fate of soldiers who have returned home from Afghanistan. One article described the lack of help or sympathy a blinded soldier received from the local Komsomol authorities when he returned to the USSR. 
As a result of his complaints one Komsomol official was dismissed and another expelled from the Communist Youth Organisation. ${ }^{37}$ Another recent feature was a full page article devoted to a question and answer session with reserve soldiers who had served in Afghanistan. The reserve soldiers are portrayed as manifesting great maturity and counsel the need for organising effective change in Soviet society. The speakers criticised the Komsomol for being removed from reality, for not doing enough to utilize the services of returning veterans or in preparing youth for army service. Both articles also deal with social problems of veterans, including those who are disabled. The Komsomolskaya Pravda articles obviously reflect a greater public awareness - and discontent - with the occupation of Afghanistan. ${ }^{38}$

Komsomolskaya Pravda has sympathetically described the members of these self-styled vigilante groups as "the children of Robin Hood". ${ }^{39}$ These vigilante groups hold secret training sessions in unarmed combat in order to mete out rough justice to black marketeers, corrupt officials, drug pushers and others they disagree with. Komsomolskaya Pravda wrote that: "They do not believe in us adults, let alone in representatives of law enforcement organs. And so they take it upon themselves to instil order in towns all over the country". This newspaper report described vigilante groups, composed of Afghan veterans, in Moscow, Novosibirsk and Dnepropetrovsk. They speak of their debt of duty to the motherland and are disillusioned about the reality of Soviet life after returning from combat duty in Afghanistan.

The theme of Afghanistan finds its way into numerous samizdat journals: Chronicle of Current Events; Information Bulletin of The Free Interprofessional Association of Workers (SMOT); Express Information; Bulletin ' $V$ '; Searches and Reflections; and Socialist - 82. In September 1981 leaflets were circulated in Novocherkassk calling on inhabitants to oppose interference in the internal affairs of other states. A month later posters appeared in Moscow with the slogan "Freedom for Poland and Afghanistan". Leaflets with the words, "Out of Afghanistan! Why are our sons and fathers dying in Afghanistan?" have appeared in Moscow, Leningrad, Tashkent, Samarkand, Kiev and the Baltic republics. ${ }^{40}$ Vyacheslav Bakhmin, one of the founders of the Working Commission for the Investigation of the Use of Psychiatry for Political Purposes, was accused in his trial of criticising the occupation. ${ }^{41}$

The Moscow Helsinki Monitoring Group expressed its support for the UN General Assembly resolution of 15 January, 1980 calling for the withdrawal of foreign troops from Afghanistan:

It is the absence of basic human rights, which provides the leadership of the USSR with the possibility of uncontrollably taking decisions on which not only the future of our country depends, but also the whole of mankind. A statc 
which does not observe basic personal rights, especially if it is one of the strongest states in the world, is dangerous not only for its own people and neighbours, but also for all people on Earth.

The signatories called on those who campaigned against the Vietnam war, among others, to strive for the USSR to carry out the UN resolution on Afghanistan. ${ }^{42}$

Among the signatories to this document was Andrei Sakharov. In his last major statement in an interview with an $\mathrm{ABC}$ correspondent before being exiled to Gorky, Sakharov urged the UN to press the Soviet Union to withdraw its armed forces. ${ }^{43}$ In his samizdat writings from Gorky, Sakharov constantly returns to the theme of Afghanistan, which he blames for the "general upsetting of the world equilibrium". In his view,

citizens have the right to control their national leaders decision-making on which the fate of the world depends. But we do not know how, or by whom, the decision to invade Afghanistan was made. The opportunity to criticise the policy of one's national leaders in matters of war and peace in our country is entirely absent. ${ }^{44}$

Sakharov blamed the invasion "for the nonratification of the SALT II treaty", the suffering brought to the Afghan people and for changing the world political situation:

They have struck a blow at detente, they have created a direct threat to peace not only in that region but everywhere . . . Soviet actions have promoted. . . an increase in military budgets and implemention of new military programmes in all major countries. ${ }^{45}$

Various Afghan guerrilla groups have recognised the role Sakharov has played in galvanising opinion against the occupation of Afghanistan. The director of The Afghan Information Centre, Peshawar, stated that many Afghans know and admire Sakharov, "because he was the first person enjoying any authority in the Soviet Union to protest the Soviet occupation of Afghanistan. We admire him and know that there are many other Soviet citizens. . . who have protested against the Soviet operation". "On a number of occasions Afghan groups have proposed an exchange of Soviet prisoners in their hands for Sakharov's freedom. The Soviets have never replied to any of their requests. ${ }^{47}$

Underground groups such as the "Democratic National Front of the Soviet Union" regard the war as problem number one and demand that the Soviet Union withdraw its army from Afghanistan. In June 1981 their proclamation and memorandum, which circulated in Estonia, complained that:

While itself condemning imperialism our country has turned into an imperialistic, colonial power which imposes its will by force on many nations beyond our frontiers. ${ }^{48}$ 
The Action Group for the Defence of the Rights of Invalids appealed to the International Red Cross to give aid to Soviet soldiers who had become invalids after serving in Afghanistan. ${ }^{49}$ Two Leningrad feminists were expelled from the USSR in the summer of 1980 after appealing to Soviet conscripts to go to prison rather than fight in Afghanistan. In a letter sent by the feminist Club "Maria", Leningrad, to the "Committee for Afghan Women" in May, 1980 they stated:

On behalf of all the women of our country, those who oppose the war, the violence and injustice, we greet you, our courageous friends against the war. In connection with the major role played by Afghan women during recent demonstrations against the Soviet occupation, you have yet again opened the whole world's eyes to the fact that during these times women stand as one of the major groups of fighters for justice. ${ }^{50}$

Pacifist groups have naturally opposed the war, and various individuals have refused to undertake their military conscription on religious and pacifist grounds - although it is not always clear if not wishing to be sent to Afghanistan is the main motive. "Free Initiative", an independent group within the peace movement in the USSR, comprising hippies and pacifists, have opposed the war. Sergei Troyansky, a member of this group, made an appeal in connection with the forthcoming International Day of The Child (June 1981):

Collective independent action in a totalitarian state is regarded as interference. Long live collective interference against the atomic weapons of the state, for the lives of Afghan children, and against the war in Afghanistan. ${ }^{52}$

Two years later a pacifist demonstration was held in Moscow where leaflets calling for an end to the war in Afghanistan were distributed. The police later conducted a two-day roundup, detaining 200 people. ${ }^{53}$ Oleg Radzinsky, a member of the unofficial Trust Group, was tried in October 1983 accused of "condemning the expansion of the Soviet Union in Afghanistan". He was also accused of writing a film script in which, when speaking of the occupation of Afghanistan, a parallel is drawn between the Soviet and Nazi regimes. ${ }^{54}$

An anonymous appeal to Religious and Peace Groups in defence of Mikhail Bombin, a Latvian peacenik and founder member of the Trust Group, described an episode which occurred in November 1985. Whilst travelling on a train from Riga to Moscow, Bombin turned to a group of soldiers. He criticised the continuation of the war in Afghanistan and the taking of the military oath. ${ }^{55}$

Oleg Alifanov, a worker in opposition to the regime, has also concluded that Soviet policy in Afghanistan is wrong. He claims that if a referendum were to be held the majority of Soviet people would 
choose to remove the troops. He asks why "young people are dying in Afghanistan"?:

I would explain the occupation ... not as setting an example for making the world revolution, not out of concern for the security of the USSR. . but out of a necessity of power.

Alifanov states that if he were to express these opinions openly he would be put in prison, "just like anyone who might dare to openly question the correctness of party decisions". 56

The Movement for Socialist Renewal, based in Leningrad, issued a long manifesto in November 1985 where they stated:

For the first time in the history of the Soviet state, the Soviet armed forces are conducting in Afghanistan an undeclared and hopeless war which brings glory neither to the Soviet Union nor to its armed forces. ${ }^{57}$

Although one would agree that it is a "hopeless war", the Movement for Socialist Renewal are wrong in stating that it is the Soviet Union's first "undeclared" war beyond her borders.

In Ukraine various dissidents and underground groups have come out in opposition to the war. Veterans, who return bring back stories of atrocities committed by Soviet troops, which arouse both anger and fear of casualties in their own immediate families. A pensioner from Lutsk described how attitudes have begun to get harsher since 1983:

The Russians conquered Afghanistan just like they conquered Ukraine and other countries. They were 'asked' to go there just like they were 'asked' to go into Ukraine in 1918. This is a new attitude - Ukrainians were not like this before. ${ }^{58}$

Western Ukrainians appear to be a particular problem for the Soviet armed forces. ${ }^{59}$ Two Soviet defectors in Afghanistan noticed that western Ukrainians, "befriended the Muslims and opposed the Soviet leadership. Some have voluntarily crossed to the side of the Mujahideen" 60

The Ukrainian Catholic activist Yosef Terelya tells how in March 1980 , during his imprisonment in a psychiatric hospital, KGB interrogators asked him about his attitude towards the dispatch of Soviet troops to Afghanistan. ${ }^{61}$ Accusations of criticising the occupation have figured in the trials of Ukrainian activists - Anatoly Marchenko, Dmitri Mazur and Leonid Malyshev. Malyshev wrote an open letter to Izvestiya and Central Committee of the CPSU in January, 1980 entitled "Get the Troops out of Afghanistan!"62 A persecuted Pentecostalist from the Ternopol' region of Ukraine told of one assault on their village by the militia where "they threatened to set fire to her house and to send her son to Afghanistan". ${ }^{63}$ 
Leonid Seryi, an Odessa worker and author of numerous samizdat documents about the plight of workers in the USSR, requested that his eldest son not be sent to Afghanistan, because:

We are not murderers and do not want anyone to die, we are for peace. . we do not want our son to come back a cripple or, still worse, to die. Or that some woman might curse our son and us, his parents, because he killed their son, brother, or father. After all, it is written in the Gospel: He that lives by the sword shall die by the sword. ${ }^{64}$

The Chronicle of the Catholic Church in Ukraine has produced some of the most radical documents opposing the war in Afghanistan. The Chronicle is the only samizdat document from the USSR to provide casualty figures of those killed in Afghanistan. The casualty figures provided in issue No. 7 of The Chronicle are from the Transcarpathian oblast' of south-western Ukraine, and in proportion to the population of the area, would tend to confirm previous reports of a disproportionate number being sent to Afghanistan from the recalcitrant non-Russian republics. Issue No. 7 of The Chronicle describes the casualties as "Gains for Moscow-losses for the Ukraine, that is how the "union" of these two republics with equal rights appears in the Afghan war". Coffins are not allowed to be opened because the officers accompanying them are not quite sure if they contain the correct corpses, and if they are mutilated. ${ }^{65}$

Issue No. 6 of The Chronicle included an Open Letter to the Defence Minister, Ustinov, which complained about Ukrainians being used by the Soviet government in colonial wars outside the USSR. They appealed to the outside world not to regard Ukrainians as "war criminals", because they have been sent against their will. Full support is given to the "Afghan freedom fighters", because "Ukraine knows the politics of genocide committed by Moscow against the Ukrainian Nation". In addition:

Russian chauvinism and the ruling military circles are responsible for the ventures in Afghanistan. It is a fact that eighty percent of the officer ranks in the Soviet armed forces are fervent chauvinists and detest human life. . . Ukrainians do not wish either to fight, nor do they want this unjust war. . . . ${ }^{66}$

A new samizdat document from Ukraine, dated simply "1985", is written in the form of an appeal from a Ukrainian to his "brother Afghan". ${ }^{67}$ The appeal begins by stating that Afghans and Ukrainians have now a common purpose - to struggle against "Russian imperialism, which is suppressing both our nations". The author of the appeal states his solidarity with the Afghans who are struggling to free their homeland, and believes that they will undoubtedly recover their freedom. The author asks the Afghans to recognise that Ukrainians found within the Soviet army are sent there against their will. Finally, the appeal claims that Moscow will be put on trial for her crimes com- 
mitted both in Ukraine and Afghanistan.

In the Muslim republic of Azerbaijan, a teacher described how, "a large majority of Muslims sympathise with the Afghan guerrillas". Coffins which arrive from Afghanistan inflame the already tense atmosphere. Muslims in the Soviet armed forces are not taken on military operations, because they have often defected to the guerrillas. ${ }^{68}$ In June 1984 the first reported demonst rations took place outside recruitment offices in the Georgian and Armenian capitals of Tbilisi and Erevan. Wives and mothers demonstrated, fearing that their husbands and sons would be sent to Afghanistan, leading to hundreds of arrests. ${ }^{69}$ Sergei Khovanski wrote that the "demonstration of protest staged in Erevan in 1985 became widely known". He also believed that these demonstrations:

. . constitute an important political factor. They bear evidence to the shifts that are taking place in the mood of the masses, at least in the periphery of the country, a new social activeness has emerged in place of the old apathy and depoliticisation. ${ }^{70}$

A Tiblisi taxi-driver noticed that many people in Georgia were "grumbling about the fact that Georgians are being sent to Afghanistan". Georgians complain of racism in the army: "They think of Georgians as 'blacks', and imagine that they will go over to the 'basmachi' if they got the chance". "1

Solidarity with the Afghans has been particularly strong in the three Baltic republics of Lithuania, Latvia and Estonia due to a feeling of a "common fate" between Afghanistan and their respective countries. One month after the occupation, 21 activists from the Baltic area sent an Open Letter to the Supreme Soviet and United $\mathrm{Na}$ tions - the first collective protest against the invasion. Concerning the Soviet-Afghan Friendship Treaty, used as "legitimacy" for being "invited" into Afghanistan, they stated:

The Baltic countries had similar treaties of friendship and mutual assistance with the USSR, and in 1940 the Soviet Union used these treaties as a pretext to bring in troops. Therefore the Estonian, Latvian and Lithuanian peoples know both the aims and the consequences of such actions. ${ }^{72}$

In Latvia leaflets have circulated demanding that "Our sons should not kill the sons and daughters of Afghans" and "Freedom for the Afghans and Latvians". "A A physician from Riga has experienced that, "Latvians are especially reluctant to go to the army, but the Russians are not much better. When relatives come to see the new soldiers off from the draft station it is a funeral occasion, as if the draftees were being sent to their graves". ${ }^{74}$

Valdo Randpere, a high ranking Estonian official who defected in 1984, claimed the possibility of being sent to Afghanistan as one reason for his decision. ${ }^{75}$ Four Estonians who fled to Sweden in 1984 also 
cited this fear as a main reason for their decision. When asked by a Swedish newspaper why they had fled they answered:

We did not want the power occupying our homeland to force us to participate in the occupation of another country. We expected to be drafted to the armed forces. Almost no Estonian may do his military service in his home country. Seventy percent of last year's draftees were sent to serve in foreign countries

- - Afghanistan, Poland, East Germany, Mongolia, the Chinese border and elsewhere. ${ }^{76}$

The "Declaration of an Unofficial Peace Group" in Estonia complained that young Estonians are "scattered to the winds throughout the vastness of the Soviet Union". They point to the:

... hundreds of young Estonians, Latvians and Lithuanians who have already met a cruel and shabby fate in the dirty imperialistic war in Afghanistan. ${ }^{77}$

The most revealing interview given by a veteran of the war appeared in the Estonian samizdat journal, Izekiri, in 1984. The interviewed soldier complains of not being able to re-adjust to civilian life in Estonia: ". . . I don't know when I'll be able to shake it off". The interviewer asks if he can erase his memories:

No. It's impossible to do that. Even if those memories are terribly painful; and there were, of course, many of those. You can't forget them - really, it cannot be done - they must remain in one's memory and others ought to learn about everything.

Those he befriended were others from the Baltic republics. The Central Asians could hardly understand Russian, and they exhibited a "blind rage" - partly because they were "fighting their own tribesmen". The interviewed soldier describes how they committed horrific massacres of civilians - and how their instructors told them to shoot anybody who tried to run-away. The soldier believed that, "one ought to, obviously, help the Afghans in some way in their struggle for their own land".

Interestingly, whilst in Afghanistan he read leaflets in Estonian and Lithuanian opposing the war. The soldiers who received those took them back home with them. If the Afghans had practiced "captive surrender" he believes everyone would have considered surrendering, and, "the soldiers are ready, even if it's between themselves and the Afghans, to conclude peace. ..". ${ }^{78}$

Lithuania has produced some of the most radical anti-war samizdat to have emerged from the USSR. Balis Gajauskas, a Lithuanian political prisoner, asked, "Has the world really forgotten how the Soviet empire was created?" He then describes Soviet conquests since World War II and concludes with the words: "How many peoples have fallen under Soviet influence because of treaties and conspiracies! Remember Afghanistan!"79 
The underground journal Ausra, March 1982, published two letters from Lithuanians serving in Afghanistan (dated March and April 1980) together with a more recent commentary. The commentary talked of the, "tragic news reaching us about Lithuanians who have fallen in Afghanistan. The dead are brought in zinc-coated coffins and buried secretly. Mothers are not allowed to see their sons". Funerals have turned into "protests against oppression and the sort of politics that compels our brothers to die for the interests of strangers". Those who return are emotionally scarred. Ausra talked of the other nations forced to participate in the war:

Ukrainians, Estonians, Latvians, Lithuanians. Under oppression themselves, they must obey the brutal orders of the Russian officers, and shed both their own and Afghan blood. ${ }^{80}$

The underground Lithuanian Youth Association published an appeal in the second issue of its samizdat journal, Juventus Academica, in 1985. On the occasion of the International Youth Year they uphold the right to "wage spiritual and human resistance against the arbitrariness, terror, and the cultural and physical genocide perpetuated by the occupying power". The appeal continues:

It has been five years now that our peers are senselessly perishing in Afghanistan, as they fulfill the so-called 'international duty' as members of the 'limited contingent of the Soviet armed forces' - in reality, becoming murderers. . .

We risk becoming the shame of the entire humanity! Therefore, the board of the Lithuanian Youth Association emphasizes - on the basis of the Universal Declaration on Human Rights, and guided by our conscience, let us boldly refuse to take the military oath and let us not be cowardly tools of the occupying power. ${ }^{81}$

A Lithuanian member of the CPSU believes that his views against the war are shared by many others, Russian and non-Russian alike, who frequent pro-establishment circles. The Soviet occupation "remains a big question mark in people's minds. Soviet soldiers are dying there for no good reason, yet people are being deliberately kept in the dark about what is going on." Through unofficial sources, they are able to obtain the information required to make judgements about Soviet policy in Afghanistan. He compares the Nazi atrocities of World War II with those committed by Soviet troops in Afghanistan. Family and friends are "not told how they were killed or where they were buried", yet casualties are high and "everyone seems to have their 'Afghan', whether he is still serving there, or has returned to the USSR as an invalid". The families of those who have lost sons in Afghanistan are "left to cope with their grief as best they can", although they are warned to stay silent.

However, he points out that "protests against the war are growing. Young people in particular are protesting more and more openly 
against the war in Afghanistan". Protests are often heard through the unofficial information grapevine throughout the USSR. Many young people bribe their way out of being sent to Afghanistan. Others, who cannot afford the expensive bribe, commit "self-mutilation: cutting off their fingers, for instance". ${ }^{82}$

- The Afghan war has had a powerful impact in Muslim Central Asia. Since 1980 there has been an appreciable increase in antiIslamic propaganda by the authorities. ${ }^{83}$ In addition, a common religious and ethnic bond with the guerrillas has aroused strong sympathy. A number of reports attest to cross-border raids into Central Asia, where literature is distributed and meetings are held between guerrillas and Central Asians. ${ }^{84} \mathrm{~A}$ Western visitor to Central Asia in 1984 heard that Afghanistan is now "widely discussed in the provinces, especially Central Asia." He found that "no one wants to go and fight in Afghanistan", and in Uzbekistan alone, bribes of between five and ten thousand rubles are offered to avoid military service. Most interestingly, he pointed to the degree of contact between the guerrillas and Central Asians:

For the first time in many years the USSR has a poorly defended border. Afghans allegedly penetrate Soviet territory bringing literature, contraband, narcotics, and even weapons. They allegedly have the support of the local populace and at times even have secret meetings with them. ${ }^{85}$

Although no samizdat from Soviet Central Asia dealing with Afghanistan has reached the West, Soviet official media have suggested that this kind of samizdat exists. Someone who listens to Radio Liberty in Tajik and Russian has told of the existence of samizdat in Tajikistan, which has increased since the war in Afghanistan. ${ }^{86}$ At least one Central Asian newspaper has mentioned the circulation of pamphlets in Central Asia which are known to have originated with Afghan guerrilla groups. ${ }^{87}$

Soviet republics bordering Afghanistan, such as Turkmenistan and Tajikistan, appear particularly vulnerable (Turkmen and Tajiks also live in Iran and Afghanistan). As early as January, 1980 Tajikistan was the only republic to begin a campaign in the media designed to demonstrate support for Soviet activity in Afghanistan. ${ }^{88}$ Radio Gorgan, broadcasting in Turkmen from Iran, was blamed by the chief of Tajikistan's Department of Propaganda for the circulation of magnitizdat-radio broadcasts taped, copied and passed around. ${ }^{89}$

In Central Asia the war has led to an appreciable rise in Islamic feeling. Attendance at mosques has risen, more people are applying to undertake religious studies, whilst others have joined secret brotherhoods led by underground mullahs. Many compared Soviet activity in Afghanistan with events in Bukhara sixty years ago. ${ }^{90}$ One Afghan student living in Tashkent since 1978 stated that "Uzbeks 
openly encouraged and praised the Mujahideen, although Russians were hostile, sometimes violently so". "Another Afghan student in Samarkand said:

The Kazakh, Turkmen, Uzbek and Tajik Soviet republics are first and foremost Muslim republics. In spirit we are free people waiting to free ourselves from Soviet power. The Russians know this, or at least they are currently learning it in Afghanistan. Many Muslims are on the side of the Afghans. ${ }^{92}$

Central Asians have proved to be reluctant to fight in Afghanistan. The use of Central Asian troops was a failure, and by March 1980 most were either sent home or not used for combat purposes. ${ }^{93}$ Two Soviet deserters remembered when they were sent to Afghanistan in 1980 , that there were 106 Tajiks in their unit: "They all refused to fight and they were sent home. A lot of Tajiks, Uzbeks and Turkmen were sent back. A few were shot on the spot but most were returned to the Soviet Union". ${ }^{94}$ An ethnic affinity with the Afghans, a common religion and dislike of Russians are given as reasons for refusing to fight and on some occasions defect to the guerrillas. A Tajik soldier on leave from Mongolia felt himself lucky to have escaped service in Afghanistan:

Mongolia is better - it's less dangerous. Many people from here have died in Afghanistan. Mothers get telegrams that their sons have been killed and their bodies are being returned. No one wants this war. No one wants to die. ${ }^{95}$

A German journalist who travelled illegally inside Afghanistan in 1985 met a Tajik deserter fighting with the guerillas. He complained of poor treatment inflicted upon Central Asians by Russian officers, who believed they sympathised with the Afghans. The Tajik said that the soldiers are "generally not inclined to fight". The authorities are having tremendous problems with casualties: "The relatives are asking for the dead bodies, especially the Central Asian Muslims, while more and more often, the Russians are burying them in Afghanistan." 96

In the second half of 1982 five people were arrested in Dushanbe, Tajikistan and charged with circulating leaflets against the occupation. They also distributed "false" announcements of the deaths of Soviet soldiers in Afghanistan, "with the aim of provoking discontent" among the population. The group purportedly had contact with guerrillas. ${ }^{9}$ Slava Denisov, also from Dushanbe, was recently arrested for collecting signatures to an appeal against the war in Afghanistan. She has been confined in a psychiatric hospital after being ruled "not responsible" for her actions. ${ }^{98}$ Hezb-e-Islami have claimed a membership of 3000 inside Central Asia, and the distribution of leaflets in Tajikistan and Uzbekistan. ${ }^{99}$

A samizdat document by a leader of the Crimean Tartar move- 
ment, Mustafa Dzhemilev, thanked Sakharov for his opposition to the occupation. At his trial in November 1983 he was asked what connection there was between Afghanistan and the Crimean Tartar question. He replied that unofficial estimates alone put the casualty rate of young Crimean Tartars from one region at 130 killed in Afghanistan. ${ }^{100}$

Sergei Khovanski describes an incident in June, 1985 among Chechens in Astrakhan. When the new recruits arrived for army service they "clashed with the military authorities when the latter told them that they would be trained for Afghanistan". Khovanski describes what happened then:

The Chechen youths categorically refused to go to Afghanistan, explaining that they did not wish to kill their Moslem coreligionists. In the course of a fierce clash, whose outcome was decided by the troops, there were wounded and killed on both sides... ${ }^{101}$

This study of opposition in the USSR to the occupation of Afghanistan has shown that it includes many varied groups, nationalities, individuals and political complexions. It is an area of opposition neglected and ignored by many commentators of the Soviet scene. Yet, if more serious attention were paid to how a multinational empire like the Soviet Union has coped in Afghanistan it would become obvious how this type of opposition is potentially explosive for the USSR. In the words of a Ukrainian engineer:

The Soviet people are tired of this war and everyone would like it to end as soon as possible. . . To be frank, no-one would object if the Afghan war ended in the same way as the war in Vietnam: that is, if our troops were withdrawn and the Afghans were left to decide things among themselves. ${ }^{102}$

\section{NOTES}

1. Sec A. Bennigsen. "Mullahs, Mujahidin and Soviet Muslims," Problems of Communism (November-December 1984), pp. 28-44.

2. See for example; Nicholas Daniloff, "Afghan War Finally Hits Soviet's Home Front," U.S. News and World Report (19 December 1985).

3. Sergei Khovanski, "Afghanistan: The Bleeding Wound". Detente. A quarterly journal devoted to understanding the Soviet Union. Spring 1986, No. 6.

4. Ibid.

5. Ibid.

6. J. Wishnevsky, "References to Afghanistan in Samizdat," Radio Liberty Research, RL 143/84.

7. "Some Soviet Citizen's Perceptions of the War in Afghanistan," Radio Liberty, RM 7-81.

8. Khovanski, op. cit.

9. "The Soviet Public and the war in Afghanistan: Perceptions, Prognoses, Information Sources," Radio Liberty, AR 4-85.

10. See Taras Kuzio, "Samizdat Against the Afghan War," Soviet Analyst (January 1986). 
11. Possev, No. 3 (1981). Translated in The Samizdat Bulletin (June 1981), No. 98.

12. M. Broxup, "The Soviets in Afghanistan. The Anatomy of a Takeover", Central Asian Survey Vol. 1, (1983), No. 4, p. 142.

13. "Interview with Mykola Movchan," Sucasnist (December 1984), p. 106. See also "Why One Soviet Defected in Afghanistan," U.S. News and World Report (24 September 1984).

14. Ausra, No. 30. See Taras Kuzio, "The 'Skirmishes' that Became a War," Arabia, The Islamic World Review (May 1985).

15. USSR News Brief, No. 10, 1986.

16. Radio Liberty, Soviet Area Audience and Opinion Research (SAAOR), SBN 5-84.

17. "Heroic Examples For Soviet Youth," Soviet Analyst (22nd January 1986). See also "Heroic Youth and Tales of Danger," The New York Times (12 November 1985).

18. A. Bennigsen, "Soviet Muslims and the World of Islam," Problems of Communism (February 1980), p. 47.

19. Taras Kuzio, "Afghanistan. Burdens of Occupation," Arabia, The Islamic World Review (December 1985).

20. Herald of Repression in Ukraine, No. 6, 1984.

21. Radio Liberty, Soviet Area Audience and Opinion Research (SAAOR). SBN 1-86.

22. See Taras Kuzio, "A War About Which the Soviet People Do Not Boast," Arabia, The 1slamic World Review (January 1986).

23. Radio Liberty. SAAOR. SBN 3-84.

24. Radio Liberty. SAAOR. SBN $1-85$.

25. Novoe Russkoe Slovo, (8 \& 9 September 1983).

26. USSR News Brief, No. 22, 1982.

27. Afghan Information Centre Monthly Bulletin (February 1984).

28. Khovanski, op. cit.

29. Radio Liberty. ARKHIV SAMIZDATA 5426 and "A Soviet Estonian Soldier in Afghanistan". Central Asian Survey, 1986, 5 (1) pp. 101-115.

30. Komsomolskaya Pravda (8 January 1986). See also "War Veterans Turn Vigilante," The Times (11 January 1986).

31. Khovanski, op. cit.

32. "Kabul-New York-Barashevo". Russkaya Mysl, 12 September 1986 and USSR News Brief, No. 17, 1986.

33. Radio Liberty. SAAOR. SBN 5-84.

34. Radio Liberty. SAAOR. BGR 1-85. See also Aaron Trehub, "What's In Store For Wounded Veterans Of The Afghanistan War?" Radio Liberty Research, RL 282/84.

35. Sobesednik. (Supplement to Komsomolskaya Pravda) (12 March 1986).

36. Molod Ukrainy (10 June 1986).

37. Komsomolskaya Pravda (5 August 1986).

38. Komsomolskaya Pravda (27 August 1986).

39. C. Walker, "Vigilantes meeting out rough justice," The Times, 21 October 1986.

40. Bohdan Nahaylo, "Bring our Boys Home - but is Andropov Ready to Listen Yet?" The Times (27 January 1983).

41. ARKHIV SAMIZDATA 4910.

42. ARKHIV SAMIZDATA 3897.

43. ARKHIV SAMIZDATA 3858.

44. A. Sakharov, "The Danger of Thermonuclear War," Foreign Affairs Vol. 61 
(1983), No. 5, p. 1014

45. RL. ARKHIV SAMIZDATA 4034.

46. F. Sartori, "Afghanistan at War," Radio Liberty Research. RL 270/84.

47. Kontinent (1984-85), No. 42 and The Times (22 May 1986).

48. RL. ARKHIV SAMIZDATA 4503.

49. RL. ARKHIV SAMIZDATA 4702.

50. RL. ARKHIV SAMIZDATA 5400.

51. See the case of Dmitri Argunov, member of the pacifist "Trust" group. RL. ARKHIV SAMIZDATA 5661.

52. RL. ARKHIV SAMIZDATA 5325.

53. USSR News Brief No. 21 (1983).

54. RL. ARKHIV SAMIZDATA 5176 and 5380.

55. RL. ARKHIV SAMIZDATA 5699.

56. "Open Letter of Oleg Alifanov to the Central Committee of the CPSU", Across Frontiers (Spring-Summer 1986), p. 37.

57. The Guardian, 22 July 1986 and RL. ARKHIV SAMIZDATA 5724. See also A. Kroncher, "Who are the authors of the Samizdat Appeal To the Citizens of the Soviet Union". Radio Liberty Research, RL. 283/86 and V. Tolz, "Predecessors of the Samizdat Appeal "To the Citizens of the Soviet Union". Radio Liberty Research, RL. 282/86.

58. Radio Liberty. SAAOR. SBN 3-85.

59. See S. Enders Wimbush and Alex Alexiev, The Ethnic Factor in the Soviet Armed Forces (Santa Monica: Rand Corporation, R-2787/1, 1982).

60. Our Correspondent. "Aghanistan in 1984," Sucasnist (June 1984), p. 110.

61. RL. ARKHIV SAMIZDATA 4989.

62. RL. ARKHIV SAMIZDATA 4872.

63. RL. ARKHIV SAMIZDATA 4759.

64. RL. ARKHIV SAMIZDATA 5324.

65. RL. ARKHIV SAMIZDATA 5413.

66. RL. ARKHIV SAMIZDATA 5410.

67. "Zvernennya Ukraintsa do brata Afghantsya". Ukrainska Dumka (25 September 1986) and Vyzvolnyj Shlakh, No. 11 (1986).

68. "Rasskasyvayut ob Afghanistanye", Possev No. 7 (1985).

69. Le Monde (16-17 June 1985).

70. Khovanski, op. cit.

71. Radio Liberty. SAAOR. SBN 8-83.

72. RL. ARKHIV SAMIZDATA 4327. English translation in ELTA Information Bulletin, (March/April 1980).

73. Khovanski, op. cit.

74. Radio Liberty. SAAOR. SBN. 3-84.

75. Radio Stock holm (22 August 1984).

76. Newsletter. Reports on Communist Activities in Eastern Europe. (Estonian Information Centre, Stockholm), No. 521/522 (July/October 1984). See also Radio Free Europe, Baltic Area SR/1. December 4/1984.

77. "Declaration of an Unofficial Peace Group in Estonia," Radio Liberty" Research, RL 230/84.

78. RL. ARKHIV SAMIZDATA 5426, op. cit.

79. RL. ARKHIV SAMIZDATA 4327.

80. RL. ARKHIV SAMIZDATA 4687. English translation in ELTA Information Bulletin (December 1982). See also "Afghan War Toll Shocks Lithuanians," The Times (26 August 1982).

81. ELTA Information Bulletin (October 1985). 


\section{Opposition in the USSR to the Occupation of Afghanistan}

82. Radio Liberty. SAAOR. BGR 4-86.

83. See M. Broxup, "Recent Developments in Soviet Islam," Religion in Communist Lands Vol. 11 (1983), No. 1, p. 31-35.

84. See A. Davis, "A View From Between the Tiger's Jaws," Arabia. The Islamic World Review (April 1983) and J. Gunston, "Afghan's Plan USSR Terror Attacks," Jane's Defence Weekly (31 March 1984).

85. Radio Liberty. SAAOR. BGR 1-85.

86. Radio Liberty. SAAOR. RM 10-83.

87. Sovetskaya Kirgiziia (30 June 1984).

88. Kommunist Tadzhikistana (26, 27 January 1980).

89. A. Hetmanek, "Spillover Effects of Religious Broadcasts in Iran on Soviet Muslims," Radio Liberty Research. RL 142/80.

90. Radio Liberty. SAAOR, SBN 2-85.

91. Radio Liberty. SAAOR. SBN 1-86, op. cit.

92. Radio Liberty. SAAOR. AR 5-83.

93. See S. Enders Wimbush and Alex Alexiev, Soviet Central Asian Soldiers in Afghanistan (Santa Monica: Rand Corporation, N-1634/1, 1981) and Taras Kuzio, "Ethnic Problems in the Soviet Army," Soviet Analyst (4 December 1985).

94. Across Frontiers (Spring-Summer 1986) op. cit. p. 108.

95. A. Nagorski, "Worries Along the Border," Newsweek (9 August 1982).

96. Bennigsen, Problems of Communism op. cit.

97. USSR News Brief No. 5 (1984).

98. USSR News Brief No. 10 (1986).

99. USSR News Brief No. 10 (1984).

100. RL. ARKHIV SAMIZDATA 5453.

101. Khovanski, op. cit.

102. Radio Liberty. SAAOR. AR 4-85.

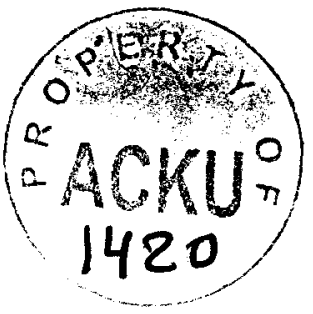

